\title{
MELANGE OFIOLÍTICA NOS METASSEDIMENTOS ARAXÁ DE ABADIÂNIA (GO) E IMPLICAÇÕES TECTÔNICAS REGIONAIS
}

\author{
ADELIR J. STRDEDER* \& ARIPLIINIO A. NILSON*
}

\begin{abstract}
OPHIOLITIC MELANGE IN THE ABADIÂNIA (GO) ARAXÁ METASEDIMENTS AND ITS REGIONAL TECTONIC IMPLICATIONS. Based on a detailed study of the structural and geological framework of the Abadiânia region (GO). It was possible to characterize an ophilitic melange petrotectonic association. This association consists of a metasedimentaty sequence, commonly referred to as Araxá metasediments, plus serpentinite bodies with podiform chromite lenses, elongated mafic bodies, and banded porphyroclastic gneisses. The contacts between these lithotypes are tectonic, represented by a $\mathrm{S}_{1}$ mylonitic folitiation. The serpentinite bodies are chemically similar to residual mantle peridotites, while the mafic bodies show geochemical affinities with tholeiitic island-arc basalts. Both are preferentially emplaced in gamet-mica-quartz schits. On a regional scale, both an evaluation of the petrotectonic characteristics of the ophiolitic melange and a lithologic and structural correlation with other areas exposing similar metasedimentary sequence were carried out. This petrotectonic association correlates with strong Bouguer gravimetric anomalies, indicating that it represents subduction trough deposits involved in thrust movements during the Late Proterozoic. In the Abadiania region, important directional displacement surfaces $\left(\mathrm{K}_{1}\right)$ are responsible for the Pirineus inflection structure and are also correlated with strong gravimetric anomalies. Thus, the regional structure in this area may represent a tectonic syntaxis originated as a consequence of trapping of small plates or magmatic arcs during the convergence of two large crustal blocks, or as the result of underthrusting of a wedge-shaped continental plate.
\end{abstract}

Keywords: Ophiolitic melange, Araxá Metasediments, Pirineus inflection.

\begin{abstract}
RESUMO A partir do estudo detalhado da estrutura e da constituição geológica da região de Abadiania (GO), pôde-se caracterizar uma associação petrotectônica do tipo melange ofiolítica. Esta associação é litologicamente constituída por uma seqüência de metassedimentos Araxá, por corpos de serpentinito com lentes de cromita podiforme, por corpos máficos alongados e por gnaisses porfirpclásticos bandados. Os contatos entre estas litologias são exclusivamente tectônicos por meio da foliação milonítica $\mathrm{S}_{1}$. Os corpos de sepentinito são quimicamente semelhantes a peridotitos residuais de manto, enquanto os corpos máficos apresentam afinidade geoquímica com basaltos toleíticos de arco-de-ilhas. Ambos estão preferencialmente alojados em granada-mica-quartzo xisto. Em escala regional, foram examinadas as características petrotectônicas da melange ofiolítica e realizada uma correlação litológica e estrutural com áreas de ocorrência de seqüências metassedimentares semelhantes àquela do Araxá. Foi observada uma boa correlação entre as ocorrências desta associação petrotectônica e fortes anomalias gravimétricas Bouguer, o que indica que esta associação é um depósito de calha de subducção envolvido em cavalgamentos que ocorreram durante o Proterozóico Superior. Na região de Abadiania (GO), importante superfícies de deslocamento direciona! $\left(\mathrm{K}_{1}\right)$ são responsáveis pela estruturação da inflexão dos Pirineus e também estão relacionadas a fortes anomalias gravimétricas. A estrutura regional, nesta área, pode representar uma sintaxe tectônica originada como conseqüência do aprisionamento de pequenas placas ou arcos magmáticos durante a convergência de dois blocos crustais maiores, ou como resultado da subducção de uma placa continental com formato em cunha.
\end{abstract}

Palavras-chaves: Melange ofiolítica, metassedimentos Araxá, inflexão dos Pirineus.

INTRODUÇÃO O entendimento da estruturação geológica do Centro-Oeste brasileiro, principalmente no que se refere às unidades Araxá, Canastra, Ibiá, Bambuí, tem se apresentado controverso desde o início da década de 70 até final da década de 80 . Inicialmente, a utilização do modelo geotectônico de geossinclinal apresentava duas interpretações conflitantes: (1) a evolução geológica teria envolvido um (Costa \& Angeiras 1971, Dardenne 1978, Campos 1978), ou (2) dois (Almeida 1967, Almeida 1971) ciclos tectônicos. Num período posterior, a utilização de conceitos de tectônica global levou a uma reinterpretação da estrutura da região, mas permaneceram as discussões quanto à evolução geotectônica em um (Cordani \& Brito-Neves 1984), ou em dois (Almeida et al. 1978, Marini et al. 1979b, Marini et al 1984) ciclos tectônicos de natureza independente.

No contexto da tectônica de placas, os diversos corpos de serpentinito e de rochas máficas que ocorrem encaixados nos metassedimentos Araxá desempenham um papel importante, por que são comparados a corpos do tipo alpino (Angeiras
1969, Berbert 1970, Thayer 1970), embora o mecanismo de seu alojamento não seja perfeitamente compreendido. Este tipo de associação, que ainda conta com lentes de mármore e de "material" quartzo-feldspático, é interpretado como uma melange ofiolítica por Drake (1980) e por Nilson (1984).

O objetivo deste artigo é apresentar a caracterização geológico-estrutural da associação litológica do tipo melange ofiolítica investigada na região de Abadiania (GO) e discutir a extensão da sua ocorrência e as suas implicações tectônicas regionais. Com isso, pretende-se propor, também, as bases de uma nova interpretação sobre a estruturação geotectônica do Centro-Oeste brasileiro.

$\mathrm{O}$ artigo pode ser dividido em duas partes essenciais. A primeira, Estruturação da melange Ofiolítica na região de Abadiania, sumariza os dados geológicos levantados por Strieder (1989) segundo uma abordagem estritamente fenomenológica; estes dados estão sendo gradativamente publicados. A segunda parte, Implicações Tectônicas Regionais, busca algumas correlações de constituição litológica e petrológica 
com as unidades semelhantes e discute a correlação dos dados de gravimetria com a localização de tais unidades, discute, também, o significado dos dados geocronológicos disponíveis. Nesta segunda parte, é adotada uma abordagem predominantemente hipotético-dedutiva para se alcançar algumas interpretações de caráter regional; contudo, sempre que necessário, faz-se ressaltar as limitações impostas a este tipo de interpretação.

CONCEITO DE MELANGE Este item tem por objetivo fornecer, ao leitor, uma noção apropriada das características geológicas da associação petrotectônica designada Melange Ofiolítica. As características de mapeabilidade, de constituição, de origem e de nomenclatura devem ser sumarizadas de antemão, já que transcorre um período relativamente longo entre a interpretação dada por Drake (1980) e esta caracterização, sem que a discussão tenha avançado.

O termo melange foi cunhado por Greenly (1919 apud McCall 1983a) para designar uma associação caótica de rochas formada por processos tectônicos. A natureza não-genética do termo deu liberdade conceitual à interpretação do significado de formações olstostromais, relacionadas à base de lâminas de cavalgamento (Robertson 1977, Leonov 1978), das melanges relacionadas ao prisma acrecionário de calhas de subducção (Hsü 1968, 1974, Gansser 1974), ou das melanges puramente tectônicas (McCall 1983b).

A formação da melange é vista como o produto da ação dos processos de fragmentação e de mistura (Hsü 1968). As melanges são unidades mapeáveis caracterizadas pela presença de blocos nativos, exóticos e/ou tectônicos de escala também mapeável, imersos em uma matriz fragmentária de material mais dúctil. A intensidade de cisalhamento imposto à matriz e aos blocos informa a magnitude dos processos tectônicos que atuaram sobre a mesma, enquanto a existência de qualquer espécie de organização interna, ou controle estratigráfico de sua ocorrência pode apontar para um processo de deslizamento gravitacional (olstostromas).

Uma melange pode ser caracterizada como: olstostromal, tectônica ou ofiolítica. Gansser (1 974) utilizou o termo melange ofiolítica para descrever unidades de rocha que possuam blocos componentes de natureza ofiolítica, sedimentar e/ou metamórfica e uma matriz serpentinítica, ou sedimentar flyschóide. Nesta conceituação, a melange ofiolítica não precisa ter uma origem inteiramente tectônica e, portanto, pode ser vista como um megaolstostroma modificado por processos tectônicos. "As melanges ofiolíticas foram, em determinado período, consideradas como depósitos de calha de subducção, mas, atualmente, parece que as instabilidades geotectônicas que resultam na formação das melanges (...) podem afetar uma zona muito mais larga que abrange as rochas da calha de subducção, do pré-arco, do arco e das bacias marginais" (McCall 1983a).

Os corpos caotizados como conseqüência de tensões internas de acomodação ou desprovidos de componentes exóticos não devem, segundo McCall (1983a), ser designados melanges. Neste caso, o termo "formações desmembradas ou deslocadas" deve ser aplicado (Hsü 1974, McCall 1983b).

GEOLOGIA DA REGIÃO DE ABADIÂNIA Conhecimento anterior Este capítulo pretende apenas situar a área dentro da visão geotectônica dominante, de forma que o leitor possa acompanhar melhor a discussão posterior.

A região de Abadiânia localiza-se na parte leste do Maciço Mediano de Goiás (Almeida 1988), ou, mais especificamente, na Faixa de Dobramentos Uruaçu (Almeida et al 1976, Marini et al. 1979b), que é essencialmente composta pelas rochas metassedimentares do "Grupo Araxá" (Fig. 4).

Esta área foi anteriormente cartografada em escala 1:100.000 por Berbet et al (1970). Neste mapeamento, foi identificada uma seqüência de rochas metassedimentares (muscovita quartzitos, grafita-muscovita-quartzo xisto e granada- mica-quartzo xisto) referida ao "Grupo Araxá", além de nove pequenos corpos de serpentinito portadores de cromíta podiforme, alojados nas rochas metassedimentares por intrusão "a frio". Além destas rochas, Berbert et al (1970) referem a presença de para-anfibolitos associados aos xistos metassedimentares e de dois pequenos "núcleos" de quartzo-feldspato gnaisse e de hornblenda-quartzo-feldspato gnaisse relacionados ao Complexo Basal de Goiás.

A ESTRUTURAÇÃO PA MELANGE OFIOLÍTICA NA REGIÃO DE ABADIÂNIA Síntese da geologia e da estruturação A reavaliação geológica e o mapeamento estrutural desenvolvidos na região de Abadiânia (Strieder 1989) mostram que esta é constituída por uma unidade granítica intensamente milonitizada, por uma seqüência metassedimentar (quartzitos, muscovita quartzitos, grafita-muscovita-quartzo xistos e granada-mica-quartzo xistos), por nove pequenos corpos de serpentinito e por quatro corpos alongados de rocha máfica (Fig. 1). Estes litotipos estão relacionados entre si através de contatos exclusivamente tectônicos manifestados pelo desenvolvimento da intensa xistosidade/foliação milonítica que marca a primeira fase deformacional $\left(D_{1}\right)$. A figura 2 é uma representação esquemática que sintetiza a estrutura e a história deformacional da melange ofiolítica na região de Abadiânia; tais características são apresentadas a seguir.

$\mathrm{O}$ intenso processo de milonitização regional gerou uma pseudo-estratigrafia ordenada que é sucessivamente composta, do topo para a base, dos litotipos apresentados acima. A intensidade do processo de milonitização causou a obliteração completa das estruturas sedimentares, embora ainda permita a verificação de gradações entre os litotipos da seqüência metassedimentar, e a quase completa obliteração das características texturais dos protólitos ígneos.

A variação na intensidade do processo de milonitização sobre a rocha granítica resultou na formação de um conjunto bandado em diversas escalas, mas que ainda preserva pequenos pods de milonitização onde é reconhecido o seu protolito inicial. $\mathrm{O}$ bandamento é dado pela concentração diferencial de porfiroclastos de quartzo, de feldspato, de muscovita e de turmalina; estes porfiroclastos remanescentes estão relacionados a uma paragênese metamórfica constituída por clinozoisitaou-granada+biotita+muscovita+albita+quartzp, que marca a foliação $S_{1}$. Assim, o conjunto deve ser denominado de gnaisse, ou de xisto porfiroclástico bandado.

Nas rochas metassedimentares, a xistosidade $S_{1}$ é marcada por um bandamento de escala milimétrica, dado pela concentração diferencial de minerais claros e escuros. Duas paragêneses metamórficas representam os tipos litológicos preponderantes da seqüência metassedimentar: a. cloritóide+anfibólio+granada+feldspato+biotita +muscovita+quartzo; b. grafita + muscovita + quartzo. Os porfiroblastos de granada têm estrutura interna rotational e, portanto, evidenciam que $S_{1}$ das rochas metassedimentares é uma superfície de cisalhamento.

As rochas máficas têm textura nematoblástica predominante para a xistosidade $\mathrm{S}_{1}$; contudo, texturas ultramiloníticas fina e grossa sugerem um protolito gabróico. A xistosidade $S_{1}$ dos serpentinitos, embora fortemente transporta por $S_{2}$, é marcada por lamelas muito grossas de serpentina com textura fitada (ribbon) formada em processo de milonitização (Maltman 1978).

A dedução da pseudo-estratigrafia originada pela fase deformacional $\mathrm{D}_{1}$ é feita a partir da análise estrutural das superfícies deformacionais da fase $\mathrm{D}_{3}$ e da avaliação da assimetria das crenulações $F_{2}$. Esta análise foi exaustivamente desenvolvida por Strieder (1989) e é apresentada e discutida por Strieder (1990).

A segunda fase deformacional $\left(\mathrm{D}_{2}\right)$ é responsável pela formação de dobras recumbentes de caráter regional. A atitude original de $\mathrm{S}_{2}(200-25 \mathrm{NW})$ é deduzida a partir da análise 


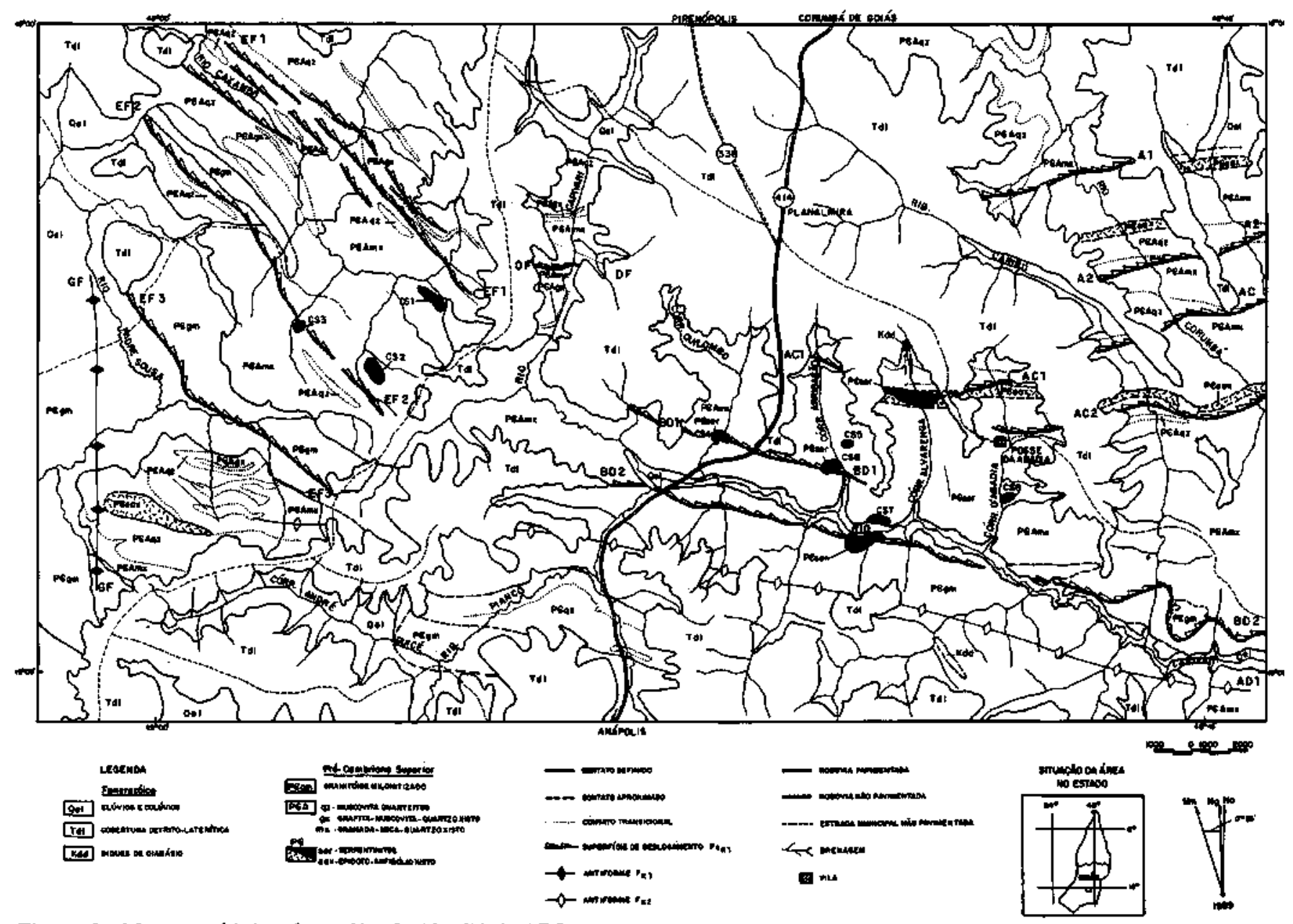

Figura I-Mapa geologico da regiáa de Abadiânia (GO)

Figure I-Geologic map of the Abadialnia region (GO)

estrutural da fase $D_{3}$, que permitiu, ainda, indicar o eixo $b_{2}$ oblíquo à vergência geral das dobras $\mathrm{F}_{2}$ e sugerir uma pequena angularidade entre $S_{1}$ e $S_{2}$. Assim, foi possível sugerir $F_{2}$ como dobras recumbentes com geometria "em bainha" de escala regional, a exemplo das estruturas identificadas nos Alpes Suíços (Lacassin \& Mattauer 1985) e no nordeste do Canadá (Henderson 1981).

A terceira fase deformacional está registrada na forma de duas superfícies conjugadas de cisalhamento direcional, que possuem atitude média $275-50 \mathrm{NE}(\mathrm{K} 1)$ e $000-45 \mathrm{E}\left(\mathrm{K}_{2}\right)$ e deslocamento levógiro e dextrógiro, respectivamente. Fraturas distensivas com atitude média 045-80SE estão colocadas como bissetriz obtusa das superfícies conjugadas. Estas superfícies têm forma sigmoidal, que pode ser acompanhada tanto nas meso-estruturas quanto na macro-estrutura regional desta fase, e dão origem a dobras do tipo kinks regionais de pequena amplitude.

Um dado importante que resulta da análise estrutural desenvolvida (Strieder 1989,1990) é a orientação do eixo $b_{2}$ original. Nesta região, ele é aproximadamente perpendicular à direção de máximo encurtamento do elipsóide geral de deformação da fase $\mathrm{D}_{3}$.

A caracterização petrográfica da trama metamórficodeformacional impressa em cada litotipo mostrou a recristalização de uma mesma paragênese metamórfica índice ao longo de todas as superfícies deformacionais identificadas. Desta forma, todo o processo deformacional foi desenvolvido dentro de condições semelhantes de T $\left(550-600^{\circ} \mathrm{C}\right)$ e de $\mathrm{P}$ ( 5 kbar) e, portanto, sugere que um único evento tectonotérmico foi responsável pela estruturação desta região.
A natureza e a forma das superfícies conjugadas de cisalhamento direcional, a sua relação com o eixo $b_{2}$ das dobras recumbentes e a pequena angularidade entre $S_{1}$ e $S_{2}$ ressaltam uma ligação cinemática entre as fases deformacionais, cuja analogia é encontrada nas zonas de cavalgamento que envolvem o transporte diferencial das nappes pela adição de uma componente de cisalhamento tipo wrench e, portanto, dão origem a dobras "em bainha" de larga escala (Sanderson 1982, Rattey \& Sanderson 1982, Coward \& Potts 1983).

A limitação da área mapeada não permite a identificação das superfícies superior e inferior da lâmina de cavalgamento, nem a caracterização regional do comportamento e do caráter espacial das superfícies conjugadas $\mathrm{K}_{1} \mathrm{e} \mathrm{K}_{2}$; porém, confirmado o caráter de rampas internas de uma lâmina de cavalgamento para as superfícies conjugadas, seria possível sugerir para a região uma estrutura do tipo foreland dipping duplexes (Boyer \& Elliott 1982).

A proposição de uma estratigrafia estritamente cronológica para as unidades litológicas descritas na área fica prejudicada pelo forte desenvolvimento da xistosidade milonítica $\mathrm{S}_{1}$. Podese, contudo, buscar informações de áreas próximas para suprir parcialmente tal deficiência. Por exemplo: algumas seções de Abadiânia e de Interlândia até Pirenópolis não mostraram evidências de qualquer superfície de cavalgamento que colocasse as duas áreas em diferentes lâminas e, por isso, pode-se correlacionar tentativamente a unidade granítica milonitizada da região de Abadiânia com o Granito Raizama de Pirenópolis. O Granito Raizama é intrusive nas rochas metassedimentares e em serpentinito e, segundo dados de Araújo \& Leonardos (1986), têm natureza tardi-Dl/pré-D2, que pode indicar a 


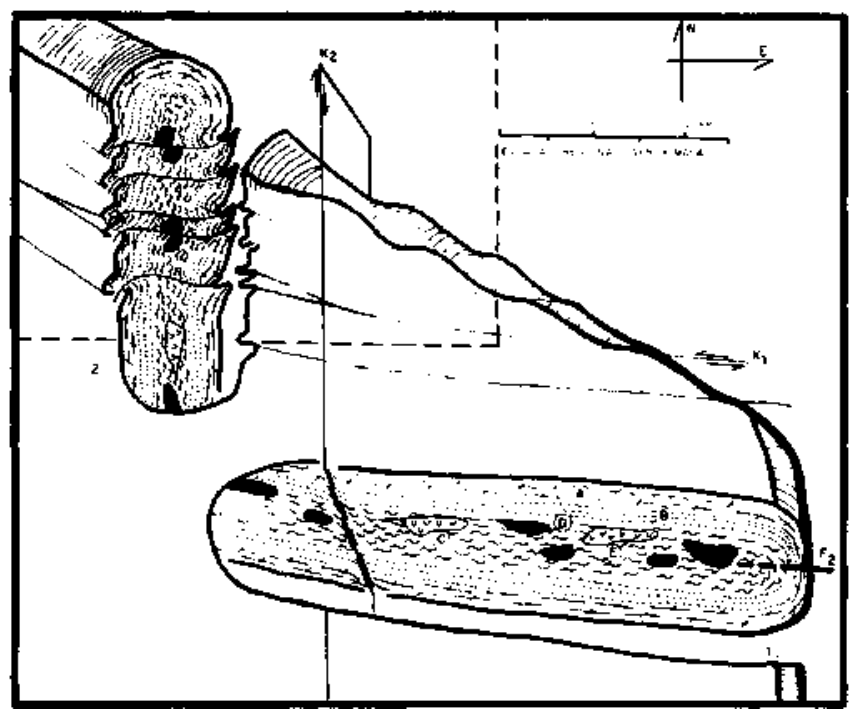

Figura 2 - Representação esquemálica tridimensional da deformação e da estrutura interna da lâmina de cavalgamento onde está situada a região de Abadiânia. Visada SE-NW oblíqua parcial da dobra recwnbente "em bainha" $F_{2}$ (L corte vertical paralelo à $K_{1}$ ) deformada por $K_{1}$ (2. corte vertical perpendicular às rampas laterais $K_{1}$ ) e por $K_{2}$. A linha tracejada delimita a localização aproximada da região de Abadiânia. Legenda: A. ortognaisse porfiroclástico; $\boldsymbol{B}$. quartzito + muscovita-quartzito; C. granada-mica-quartzo xisto, D. corpo de serpentinito; $\boldsymbol{E}$. corpo de epídoto-anfibólio xisto Figure 2 - Threedimensional representation of the internal constitution and deformation of the thrust sheet in wich the Abadiania region is located. Oblique SE-NE partial view of the $\mathrm{F}_{2}$ sheath recumbent fold (1. vertical section paralie to $\mathrm{k}_{1}$ ) deformed by $\mathrm{K}_{1}$ (2. vertical section perpendicular to the $\mathrm{K}_{1}$ lateral ramps) and $\mathrm{K}_{2}$. Dashed line define the aproximate location of the Abadiânia region. Legend: A. porphyroclastic ortogneiss; B. quartzite + muscovite quartzite; $\mathbf{C}$. garnet-mica-quartz schist; D. serpentinite body; E. epidote-amphibole schist body

relação crono-estratigráfica dos granitos milonitizados da região de Abadiânia.

A definição da relação dos corpos de serpentinito e de epídoto-anfibólio xistos com as rochas metassedimentares é mais difícil, pois, em todas as ocorrências registradas na Região Centro-Oeste, não são observados contatos claramente intrusivos, mas, apenas, uma concordância estrutural entre a sua foliação e aquela das rochas encaixantes (Berbert 1970, Danni \& Teixeira 1981, Nilson 1984). As relações temporais entre estes litotipos devem, então, ser analisadas dentro de um contexto estrutural que possa estabelecer as condições e a época do alojamento.

Os corpos de rochas básicas e ultrabásicas metamorfizadas têm impressas todas as superfícies deformacionais observadas na região e apresentam clara equivalência entre a deformação interna e aquela verificada na sua encaixante. A intensidade de desenvolvimento da xistosidade milonítica S1 obliterou qualquer estrutura pré- $\mathrm{D}_{1}$ nestas rochas e, assim, pode-se apenas estabelecer que o seu alojamento tectônico foi sin-Dl.

Protolito das rochas máficas e ultramáficas Embora a natureza petrográfica e geoquímica dos cromititos relacionados aos vários corpos de serpentinito encaixados nos metassedimentos Araxá seja relativamente bem conhecida (Berbert1970, Thayer 1970, Danni \& Teixeira 1981, Nilson 1984), a composição e a afinidade geoquímica dos corpos de serpentinito e de rochas máficas não têm recebido a mesma atenção.

A utilização da composição química dos serpentinitos para avaliar o seu significado petrotectônico foi discutida por
Strieder (1989); foi demonstrado, pela utilização da composição da cromita como um marcador inerte, que a serpentinização ocorreu de forma virtualmente isoquímica. Assim, foi possível utilizar a composição química dos serpentinitos em alguns diagramas discriminantes e verificar a sua afinidade geoquímica. Na Figura 3A, o alto conteúdo em $\mathrm{NiO}$ relativamente ao $\mathrm{Cr}_{2} \mathrm{O}_{3}$ mostra que os serpentinitos da região de Abadiânia são geoquimicamente comparáveis aos peridotitos alpinos; esta afinidade também é ressaltada no diagrama $\mathrm{FeO}^{*}-\mathrm{MgO}-\mathrm{Na}_{2} \mathrm{O}+\mathrm{K}_{2} \mathrm{O}$ (Fig. 3B), onde os serpentinitos estão composicionalmente restritos ao campo dos peridotidos metamórficos de manto. A composição normativa dos serpentinitos indica uma rocha harzburgítica, compatível com a cromita podiforme altamente aluminosa associada (Fig. 3C). Portanto, a composição química dos serpentinitos sugere um protolito do tipo harzburgito residual de manto.

As rochas máficas, por outro lado, provavelmente se originaram a partir de um protolito gabróico, por que exibem texturas miloníticas com clastos muito grossos de anfibólio. Confirmada a ausência de efeitos de processos acumulativos nestas rochas, foi possível concluir que as relações entre os seus elementos menores e imóveis evidenciam uma afinidade geoquímica com basaltos toleíticos de arco-de-ilhas (Strieder 1989).

Caracterização da melange ofiolítica As características enumeradas acima têm normalmente levado a interpretações controversas do que representam os "contatos a frio", principalmente devido à falta de uma caracterização detalhada da geologia estrutural das rochas ultramáficas e das seqüências nas quais estão encaixadas. Estas rochas, ao que parece, são vistas como corpos cuja "aloctonia" (intrusão forçada?) em grandes falhas regionais imprime uma foliação metamórfica desvinculada da deformação das rochas encaixantes (Danni \& Teixeira 1981); ou seja, somente os corpos máfico-ultramáficos teriam caráter alóctone, mas não toda a seqüência onde estão encaixados.

$\mathrm{O}$ condicionamente tectônico destes corpos está certamente controlado por extensas falhas regionais registradas pela xistosidade milonítica $\mathrm{S}_{1}$ Os corpos de serpentinito e de epídoto-anfibólio xisto estão localizados na base da pseudoestratigrafia gerada pelas falhas regionais de baixo ângulo $\left(D_{1}\right)$. As imbricações tectônicas resultantes da superposição das fases deformacionais posteriores omitem, por adelgaçamento e por rompimento, um ou outro dos litotipos envolvidos na deformação e isso faz com que os corpos básico-ultrabásicos metamorfizados estejam em contato não só com o granadamica-quartzo xisto, mas também com outros litotipos.

Os corpos básico-ultrabásicos metamorfizados têm, então, um controle estrutural específico e o seu alojamento foi realizado a baixas temperaturas ("contato a frio"), em condições de metamorfismo regional. $\mathrm{O}$ alojamento destes corpos tem caráter tectônico, pois se deu em zonas de intenso falhamento, sob um regime de deformação dúctil-rúptil; as deformações impressas nestes corpos estão vinculadas às deformações sofridas por todo o conjunto de rochas que compõem a lâmina de cavalgamento. Por outro lado, o fato destes corpos registrarem a xistosidade $S_{1}$ não significa, necessariamente, que o seu alojamento tenha sido anterior àquela fase deformacional; se examinadas estas características e o seu posicionamento no pseudo-estratigrafia $D_{1}$, pode-se sugerir que este alojamento ocorreu sin- $D_{1}$.

A intensidade da deformação $\mathrm{D}_{1}$, por obliterar feições geradas durante o aumento gradativo na intensidade de milonitização, dificulta a caracterização imediata de tal associação como uma melange ofiolítica. Por exemplo: o posicionamento dos fragmentos ofiolíticos ao longo de um único horizonte poderia dar lugar a caracterizações do tipo "formações desmembradas". Esta interpretação, no entanto, sofre restrições principalmente devido à quantidade de fragmentos; se 0 desmembramento ocorreu sin- $\mathrm{D}_{1}$ os fragmentos seriam inter- 

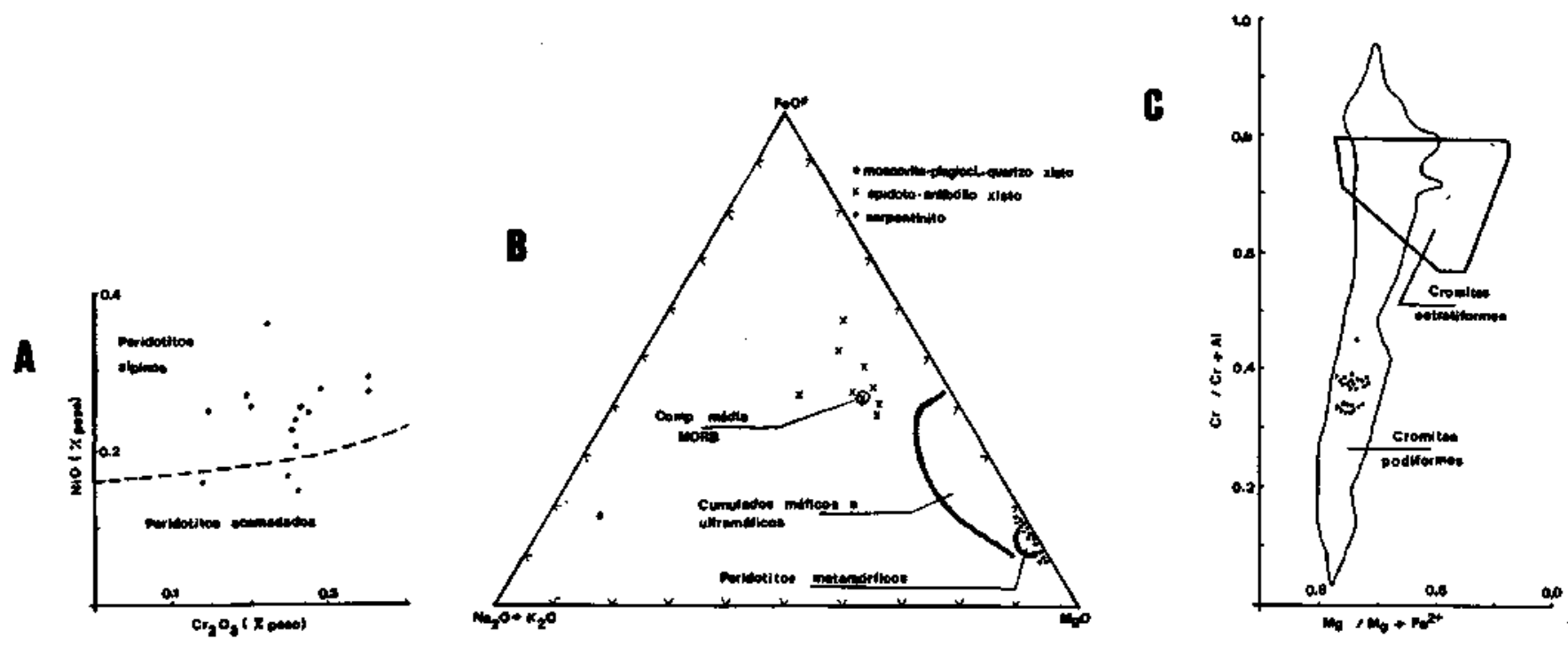

Figura 3 - Diagramas discríminantes da afinidade geoquímica dos serpentinitos e dos cromititos de Abadiaria (GO). A. Diagrama $\mathrm{NiO} \times \mathrm{Cr}_{2} \mathrm{O}_{3}$ que distingue peridotitos alpinos de peridotitos de intrusões acamadadas (Malpas \& Stevens 1977); B. Diagrama triangular $\mathrm{FeO}^{*}-\mathrm{MgO}-\mathrm{Na}_{2} \mathrm{O}+\mathrm{K}_{2} \mathrm{O}$, que apresenta a composição química relativa das rochas máficas e ultramáficas. Campos composicionais de acordo com Coleman (1977); C. Diagrama $\mathrm{Cr}^{3+} / \mathrm{Cr}^{3+} \mathrm{Al}^{3+} v \mathrm{v}$. Mg/Mg $\mathrm{Fe}^{2+}$ para a composição da cromita primária

Figure 3 - Geochemical affinity discriminal diagramas for the Abadiânia (GO) serpentinites and chromitites. $\mathbf{A}$. $\mathrm{NiO} v s \cdot \mathrm{Cr}_{2} \mathrm{O}_{3}$ diagram distinguishing alpine peridotites from layered intrusion peridotites (Malpas \& Stevens 1977); B. $\mathrm{FeO}^{*}-\mathrm{MgO}-\mathrm{Na}_{2} \mathrm{O}+\mathrm{K}_{2} \mathrm{O}$ triangular diagram showing the relative chemical composition of the mafic and ultramafic rocks; compositional fields from Coleman (1977); C. $\mathrm{Cr}^{3+} / \mathrm{Cr}^{3+} \mathrm{Al}^{3+} v s . \mathrm{Mg} / \mathrm{Mg}+\mathrm{Fe}^{2+}$ diagram showing the primary composition of the chromite

pretados como boudins do processo de milonitização e, de alguma forma, deveriam deixar impressa a sua ligação: presença de fragmentos menores do que aqueles representados pelos corpos localizados, ou níveis mais contínuos de xisto magnesiano dentro da seqüência metassedimentar.

Por outro lado, nos exemplos de melange ofiolítica com idade fanerozóica, é comum observar zonas onde fragmentos de ofiolito menores do que $100 \mathrm{~m}$ de comprimento estão concentrados. Este tipo de ocorrência não foi registrado na região de Abadiânia. Porém, deve-se ter em mente que os fragmentos de serpentinito com aquela dimensão devem estar completamente talcificados e/ou cloritizados e que todos os fragmentos deste tipo de ocorrência devem estar muito estirados, talvez transformados em bandas/lentes descontínuas, devido a intensidade da milonitização regional $\left(\mathrm{D}_{1}\right)$.

Regionalmente, Drake (1980) refere-se às "lentes" de mármores nos metassedimentos Araxá também como possíveis fragmentos. Este litotipo não é encontrado na região de Abadiânia; porém, Araújo (1981) menciona lentes de mármore calcítico encaixados em granada-mica-quartzo xistos logo a norte da área de Abadiânia. A deposição de sedimentos químicos em seqüências do tipo grauvaquiana, ou turbidítica não é comumente esperada; portanto, é possível que estas lentes constituam olistólitos, ou mesmo fragmentos tectônicos. Desta forma, a ocorrência das lentes de mármores encaixadas em granada-mica-quartzo xistos sugere que as mesmas se localizam em horizontes próximos daqueles dos corpos de serpentinito e de epídoto-anfibólio xistos e que a unidade de granada-mica-quartzo xisto constituiria um horizonte com fragmentos tectônicos de natureza exótica. Este horizonte é, na realidade, a unidade que deveria ser mais apropriadamente reconhecida como uma melange ofiolítica.

A intensidade do processo milonítico $\mathrm{D}_{1}$ somente permite a identificação de melange ofiolítica em Abadiânia devido à presença dos tipos litológicos contrastantes. Esse horizonte de melange ofiolítica e toda a pseudo-estratigrafia originada em $\mathrm{D}_{1}$ foram subseqüentemente envolvidos nos processos deformacionais internos $\left(\mathrm{D}_{2}, \mathrm{D}_{3}\right)$ da lâmina de cavalgamento, que foram responsáveis por repetições isoclinais e imbricações. Este tipo de complexidade interna para melanges ofiolíticas também é descrito por Ballance \& Sporll (1979) e por McCall (1983b).

IMPLICAÇÕES TECTÔNICAS REGIONAIS A grande complexidade geológico-estrutural da unidade Araxá tem dificultado o entendimento do significado tectônico da interpretação esboçada por Drake (1980). A principal limitação que enfrentará qualquer trabalho sobre a evolução geológica regional pelo estabelecimento de correlações dentro de uma litoestratigrafia formal, será a não-caracterização das lâminas de cavalgamento e a não-distinção entre os terrenos alóctones e os autóctones que marcam situações de convergência de placas. Estas tarefas são de grande importância para a definição do quadro geológico e tectônico da região Centro-Oeste. Neste sentido, a apreciação do significado tectônico regional da Melange Ofiolítica nos metassedimentos Araxá deve ser cautelosa.

O que se pretende apresentar é a análise crítica de algumas feições geológicas que emergem principalmente da evolução estrutural reconhecida na região de Abadiânia (Strieder 1989, 1990). Deste modo, embora se conheçam as limitações discutidas anteriormente, é necessário que alguns trabalhos anteriores sejam examinados dentro do seu contexto local e analisados dentro da perspectiva aqui esboçada, enquanto outros devem ter sua utilização limitada devido ao caráter predominantemente interpretative que oferecem. Esta análise abrange preferencialmente as unidade que, devido às suas características, são parte integrante ou podem estar correlacionadas aos metassedimentos Araxá e que disponham de suficientes dados geológico-estruturais.

A base para esta discussão é uma adaptação (Fig. 4) do Mapa Geológico da Faixa Brasília de Marini et al (1979a) ao qual é acrescentada a continuidade norte dos Grupos Tocantins e Estrondo, baseada principalmente em Hasui et al (1980a).

A ocorrência e a estruturação da melange dos metassedimentos Araxá e das unidades semelhantes A ocorrência de fragmentos ofiolíticos é bastante comum dentro dos metassedimentos Araxá e, embora os corpos de serpentinito e de epídoto-anfibólio xisto estejam alongados e orientados segundo as linhas estruturais locais, não existe 


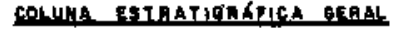
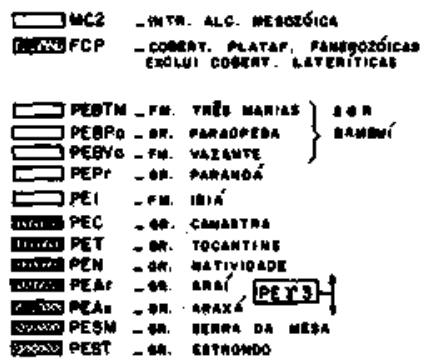

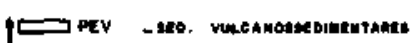

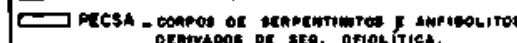

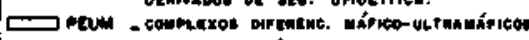

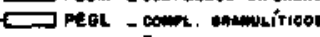

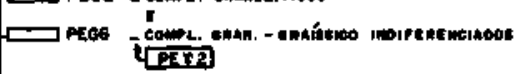

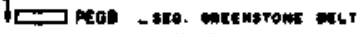
PErT.

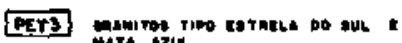

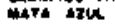

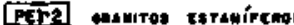

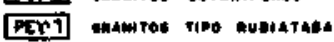

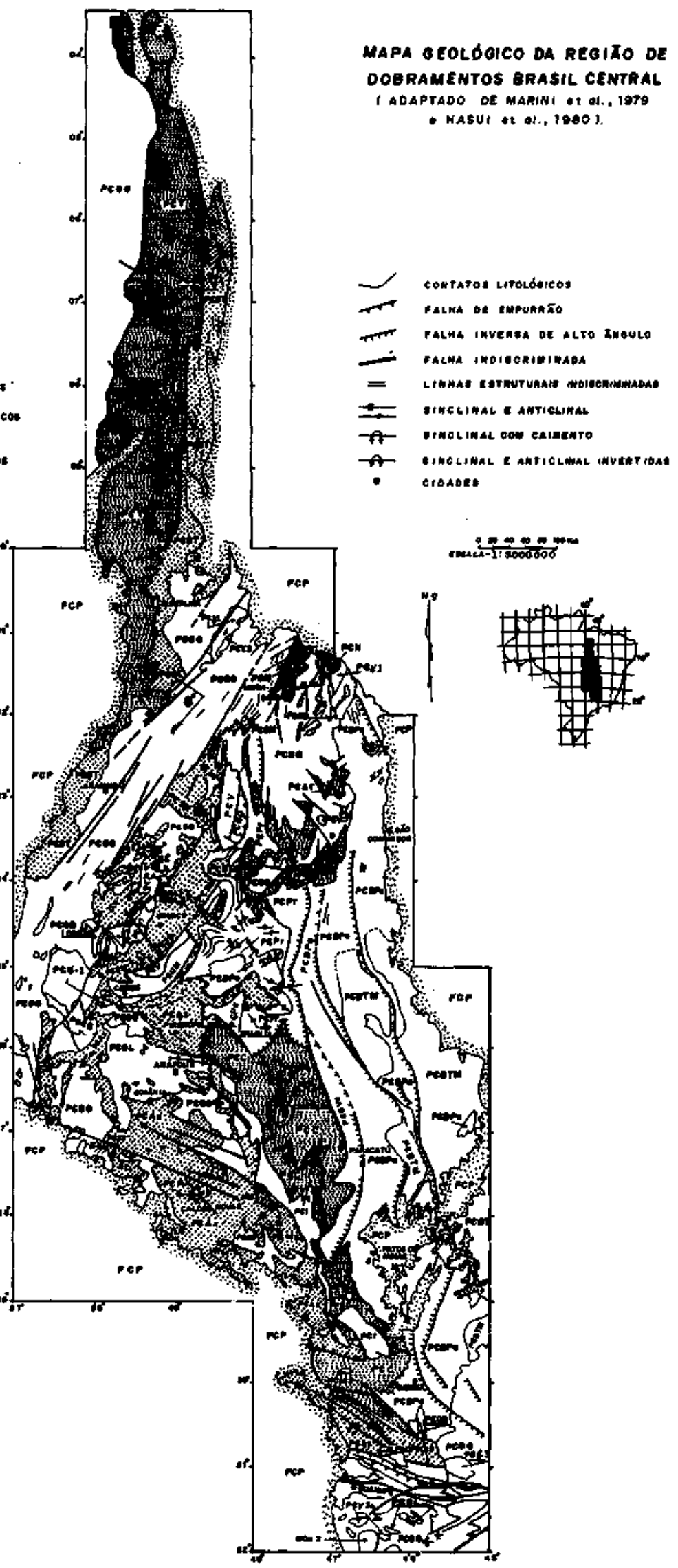

Figura 4- Mapa geológico da região de Dobramentos do Brasil Central (adaptação a partir de Marini et al. 7979a e de Hasui et al. 1980a)

Figure 4 - Geologic map of the Central Brasil Fold Region (adapted from Marini et al. 1979a and from Hasui et al. 1980a) 


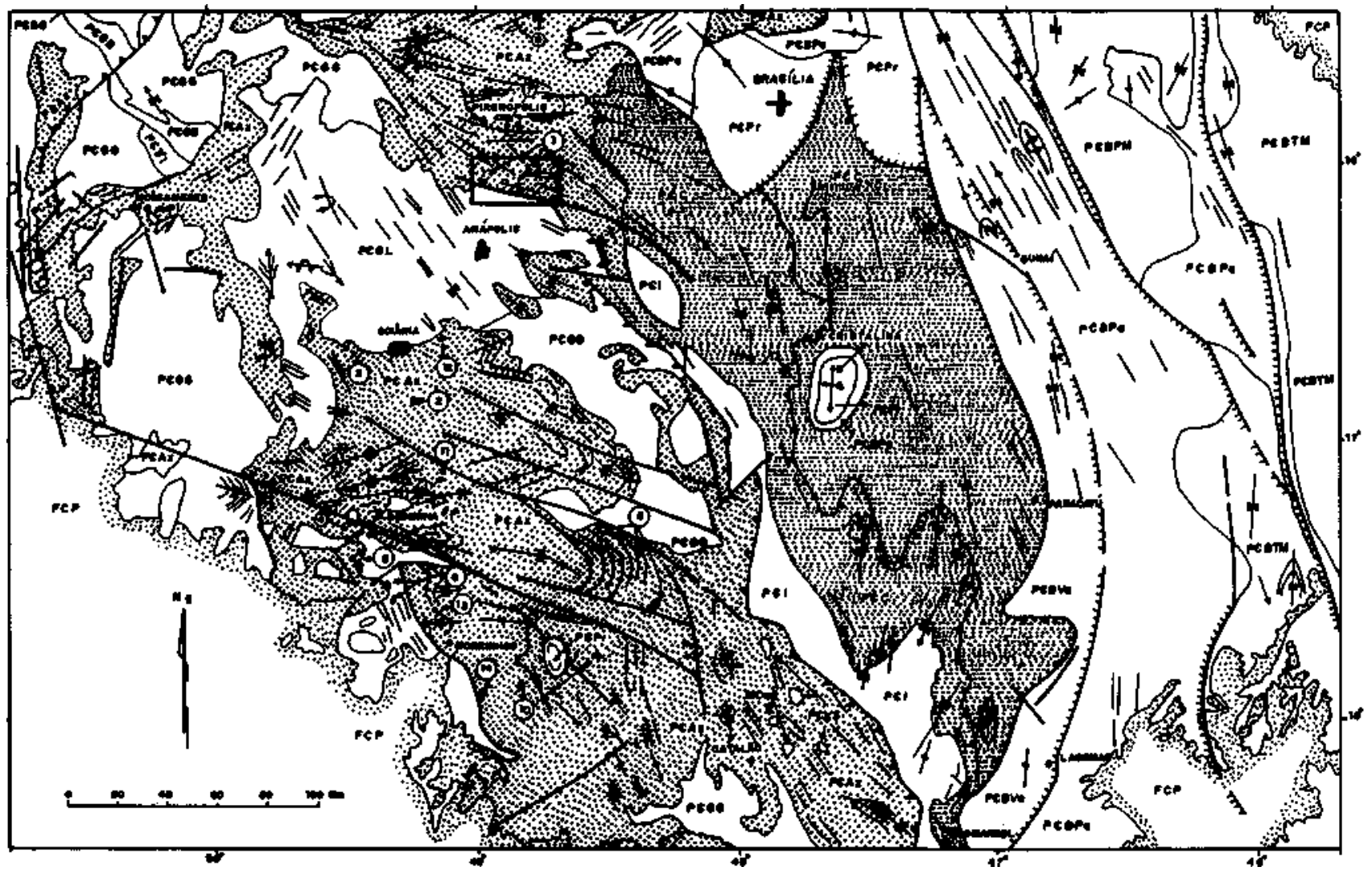

Figura 5 - Ampliação parcial do Mapa Geológico da figura 4 para a locação dos corpos de serpeníinito e "anfibolito" mais importantes que ocorrem na melange ofiolítica. Identificação dos corpos e fontes de referência: 1. Abadiânia (Mello et al. 1968, Berbert et al. 1970, Strieder 1989); 2. Morro Feio (Melo \& Berbert 1969, Millioti 1978); 3. Trindade (Nilson \& Moita 1969 ); 4. Cromínia-Mairípotaba (Nilson et al. 1969, Corrêa \& Lessa 1969, Araújo et al. 1980); 5. Pontalina (Araújo et al. 1980); 6. Dois irmãos (Nilson \& Reais 1969, Araújo et al. 1980); 7. Pirenópolis (Rosito \& Araújo 1969, Araújo 1981); 8. Santa Cruz e Goiás (Martins \& Roesner 1986); 9. Parte Norte dos Pirineus; 10. Caldas Novas (Braun 1969, Drake 1980); 11. Fazenda Santa Rica (Araújo et al. 1980); 12. Bonfinópolis (Corrêa \& Bittencourt 1968); 13. Morrinhos I (Batista 1969); 14. Morrinhos II (Braun 1969) Figure 5 - Partial ampliation of the geologic map of Figure 4 to locate the most important serpentinite and "amphibolite" bodies that occur in the ophiolitic melange. Identification of bodies and reference sources: 1. Abadiânia (Mello et al. 1968, Berbert et al. 1970, Strieder 1989); 2. Morro Feio (Melo \& Berbert 1969, Millioti 1978); 3. Trindade (Nilson \& Motta 1969); 4. Cromínia-Mairipotaba (Nilson et al. 1969, Corrêa \& Lessa 1969, Araújo et al. 1980); 5. Pontalina (Araújo et al. 1980); 6. Dois irmãos (Nilson \& Reais 1969, Araújo et al. 1980); 7. Pirenópolis (Rosito \& Araújo 1969, Araújo 1981); 8. Santa Cruz e Goiás (Martins \& Roesner 1986); 9. Parte Norte dos Pirineus; 10. Caldas Novas (Braun 1969, Drake 1980); 11. Fazenda Santa Rica (Araújo et al. 1980); 12. Bonfinópolis (Corrêa \& Bittencourt 1968); 13. Morrinhos I (Batista 1969); 14. Morrinhos II (Braun 1969)

qualquer espécie de alinhamento evidente em sua distribuição regional. Os corpos máficos e ultramáfícos mais importantes foram locados no mapa geológico regional ampliado (Fig. 5), onde são apresentadas as fontes de referência utilizadas.

Conforme sumarizado por Nilson (1984), os corpos de serpentinito a sul da inflexão dos Pirineus têm menos do que 5,0 km de comprimento; têm xistosidade dos bordos sempre concordante com aquela impressa nas encaixantes (granadamica-quartzo xistos) e invariavelmente possuem uma zonação de bordo com espessura irregular causada por trocas metassomáticas resultantes da interação química entre tipos litológicos composicionalmente muito contrastantes. Em vários corpos de serpentinito, são descritos bolsões lenticulares de pequena extensão $(<2,0 \mathrm{~m})$ e espessura $(<0,5 \mathrm{~m})$ formados por cromita tipicamente podiforme (Berbert 1970, Thayer 1970). Já, os corpos de epídoto-anfibólio xisto encaixados nas rochas metassedimentares, embora menos estudados, têm tamanho mais expressivo, da ordem de 10-12 km de comprimento aflorante. Além dos corpos principais locados na figura 5, os textos e os mapas que compõem os projeto Goiânia (Barbosa 1970) e Goiânia II (Pena 1975) fazem inúmeras referências a xistos magnesianos (serpentinitos, talco xistos e/ou clorita xistos), ou a anfibolitos que não têm expressão na escala em que são apresentados.

Em toda a região onde afloram os metassedimentos Araxá, é verificada a presença de corpos de serpentinitos, de xistos magnesianos e de epídoto-anfibólio xisto, ou de anfibolito, cujas características gerais assemelham-se àquelas descritas para os corpos estudados na região de Abadiânia. Isto dá condições para que se estenda a ocorrência da melange ofiolítica para a maior parte das áreas abrangidas pelos metassedimentos Araxá (Fig. 5), ou unidades similares.

A análise metamórfico-deformacional da região de Abadiânia (Strieder 1989) mostra que toda a deformação e o metamorfismo impressos nas unidade litológicas aí aflorantes foram desenvolvidos em um único evento tectônico e que as feições condicionadoras de todo o processo são nappes e superfícies de cavalgamento. É dentro de um contexto tectônico onde estes processos têm um papel preponderante que são analisadas algumas feições geológicas de caráter regional.

A primeira e mais importante feição geológica a ser analisada é a Inflexão dos Pirineus (concepção de Costa \& Angeiras 1971). Consideradas as características, a natureza e a influências das superfícies de deslocamento direcional (Ridley 1982, 
Lagarde \& Michard 1986) e a evolução metamórfico-deformacional da região de Abadiânia (Strieder 1989), pode-se interpretar a Inflexão dos Pirineus como a expressão geomorfológica do condicionamento estrutural imposto às estruturas $D_{1}$ e $D_{2}$, que são infletidas para $W$ pelas superfícies conjugadas $\mathrm{K}_{1}$ e $\mathrm{K}_{2}$ (Fig. 2 e 5 ).

Outras feições geológicas de caráter regional são analisadas por região de ocorrência:

a. Áreas em Goiás: Próximo à Cromíhia (GO), a melange é representada por um alinhamento local de direção aproximadamente EW, com mais de $30 \mathrm{~km}$ de extensão, onde ocorrem duas dezenas de corpos de serpentinito e de clorita-talco xistos; os blocos maiores possuem 4-5 km de comprimento e os blocos menores, 200 a $700 \mathrm{~m}$ (Nilson et al. 1969, Araújo et al 1980, Nilson 1984). Os corpos maiores estão alinhados paralelamente à xistosidade principal $\left(\mathrm{S}_{2}\right)$ das rochas metassedimentares encaixantes. Tanto os corpos ultramáficos, quanto as rochas encaixantes exibem, além da xistosidade $S_{2}$, duas direções de crenulação sub-ortogonais entre si.

Outras ocorrências de pequenos corpos de serpentinito, de clorita-talco xisto e de "anfibolito", agrupada, ou isoladamente alojados nos metassedimentos Araxá representam áreas onde se pode caracterizar a melange ofiolítica com segurança. As localidades de Goiás que possuem estas características, por exemplo, são: Pontalina (Nilson \& Reis 1969, Nilson et al 1969, Araújo et al 1980), Trindade (Nilson \& Motta 1969), Bonfinópolis (Corrêa \& Bittencourt 1968) e Pirenópolis (Rosito \& Araújo 1969, Araújo 1981). De outro modo, o corpo serpentinítico de Morro Feio possui aproximadamente $5 \mathrm{~km}$ de comprimento (Mello \& Berbett 1969) e constitui um bloco exótico isolado no granada-mica-quartzo xisto Araxá.

Na região de Santa Cruz de Goiás, Braun (1969) sugere uma estrutura na qual se associam falhas de empurrão e falhas transcorrentes EW que "parecem demonstrar que grandes blocos em forma de escamas deslocaram-se diferencialmente em conseqüência de um esforço tangencial que atuou num sentido oriental...". Embora esta estrutura não esteja completamente caracterizada devido à falta de uma análise estrutural do processo deformacional, ela é semelhante àquela da região da inflexão dos Pirineus, onde as falhas transcorrentes EW (Kl) constituem a causa primordial das flexuras que se impõem sobre as dobras recumbentes D2 (Strieder 1990).

Mais recentemente, foi realizado um mapeamento na região de Santa Cruz de Goiás (Projeto Santa Cruz; p. ex.: Martins \& Roesner 1986), onde foi identificada uma fase deformacional anterior ao desenvolvimento de superfícies de cavalgamento $(D n+2)$ e falhas direcionais E-W e ENE. A estruturação proposta, no entanto, sugere o imbricamento de alguns litotipos e, desta forma, o condicionamento geral da estrutura parece estar relacionado a rampas frontais internas de uma lâmina de cavalgamento com estrutura do tipo hinterland dipping. As falhas direcionais da área recebem a mesma interpretação geral dada por Braun (1969).

A região de Mossãmedes também representa uma constituição geológica que pode ser parcialmente comparada àquela da região de Abadiânia, embora o tipo de estruturação regional parece ser diverso. Simões (1984) e Barbosa (1987) descreveram e individualizaram uma seqüência de metassedimentos referidos ao "Grupo Araxá", intimamente imbricada com rochas gnáissicas bandadas e xistos feldpáticos.

Num quadro mais regional, é importante analisar a figura 4: nela são apresentadas algumas falhas inversas de baixo e alto ângulo que separam as unidades honotaxiais do "Grupo Araxá" (Fuck \& Marini 1979), o "Complexo GranitoGnáissico", o Grupo Paranoá, a Formação Ibiá e as unidade do Grupo Bambuí. Estas estruturas têm sido interpretadas como tardias (idade Brasiliana) dentro de uma evolução tectônica que define seus primeiros traços no Arqueano e vem se desenvolvendo até o Proterozóico Superior por meio de sucessivas reativações de falhas profundas, que possuem natureza essenci- almente vertical (Almeida et al 1976, Fuck \& Marini 1978, Marini et al. 1979b).

A não definiç̧ão da seqüência de lâminas de cavalgamento torna limitada a abrangência da caracterização da melange ofiolítica, no sentido de que não se pode esclarecer precisamente quantas e quais lâminas de cavalgamento foram envolvidas e são marcadas pelo desenvolvimento de melange ofiolítica. Outro fator importante e não claramente definido é a extensão e o grau de desenvolvimento do processo milonítico que marca a primeira fase deformacional $\left(\mathrm{D}_{1}\right)$. A falta destas definições dificulta, por exemplo, a verificação da extensão e da importância das intrusões graníticas tardi- $\mathrm{D}_{1} /$ pré- $_{2}$, que tem sido genericamente referidas ao "Complexo Basal Goiano".

O grau de imbricamento interno das lâminas de cavalgamento, a intensidade e a complexidade da deformação que causa esse imbricamento podem estar envolvidos em muitas das discordâncias estruturais reconhecida, enquanto a intensidade da deformação, traduzida principalmente no grau de desenvolvimento da foliação/xistosidade milonítica $S_{1}$, parece estar dificultando o reconhecimento do protolito inicial das rochas gnáissicas bandadas.

b. Áreas em Tocantins Na parte norte da Faixa de Dobramentos do Brasil Central, o "Supergrupo Baixo Araguaia" tem sido correlacionado ao "Grupo Araxá" e ao "Grupo Canastra". Os corpos de serpentinito têm tamanho entre 5 e $70 \mathrm{~km}$ de comprimento, estão alinhados aproximadamente N-S e possuem xistosidade de bordo, por vezes suavemente ondulada e crenulada, mas que mostra concordância com as superfícies deformacionais impressas nas encaixantes (Gorayeb 1989). Para o extenso corpo de serpentinito de Quatipuru (Pará), Cordeiro \& McCandless (1976) admitem a natureza peridotítica (harzburgito) e reconhecem lentes de dunito com pequenos bolsões de cromita podiforme associados, raras lentes de piroxenito e intrusões básicas (diabásios, olivina-basaltos e gabros); o contato com as encaixantes é feito por meio de uma zona de brechação que inclui fragmentos de rocha ultramáfica e de chert. Estas características permitem sugerir que os corpos ultramáficos alojados nestas unidades metassedimentares representam uma estrutura ofiolítica desmembrada.

A intensidade de deformação do "Supergrupo Baixo Araguaia", como sobressai no trabalho de Abreu \& Hasui (1976), parece ser menor do que aquela manifestada na região de Abadiânia; porém, reconhecem dobras intrafoliais $\left(\mathrm{F}_{1}\right)$ e dobras métricas a decimétricas com ápices espessados resultantes de fases $\mathrm{D}_{2}$ com caráter holomórfico. A estratigrafia da região abrangida pelo "Grupo Estrondo" é composta por uma unidade inferior de quartzitos e de moscovita quartzitos que gradam para uma unidade superior composta por biotita xistos e estaurolitagranada-biotita xistos (Abreu 1978); ambas as unidades contêm corpos de serpentinito, de xistos magnesianos e de anfibolito. c. Areas no sudoeste de Minas Gerais Dobras recumbentes de grande amplitude foram propostas por Teixeira \& Danni (1978) e por Schmidt \& Fleischer (1978) para o sudoeste do Estado de Minas Gerais. No entanto, Heilbron et al (1987) interpretam a seqüência Araxá-Canastra como em posição normal e geram uma controvérsia de interpretação. A falta de referência a grafita-moscovita-quartzo xistos dificulta uma comparação direta com a pseudo-estratigrafia estabelecida na região de Abadiânia; porém, a apresentação de uma lito-estratigrafia formal por Heilbron et al (1987) sugere uma semelhança na constituição geológica e uma inversão da seqüência quando comparada àquela da região de Abadiânia. A observação dos mapas e dos perfis geológicos e as descrições dos litotipos fornecidas por Heilbron et al (1987) podem sugerir a ocorrência de imbricações tectônicas adicionais além daquelas referidas à base da "Seqüência Araxá-Canastra"e à Seqüência da Base da Serra do Tabuleiro. Além disso, o exame da distribuição espacial das foliações e das lineações principais e os efeitos das superposições das fases finais sugere, também, uma compatibilidade no estilo deformacional entre as duas áreas. 
Neste ponto, é importante destaca que, embora a região da Serra da Canastra possa ser litológica e estruturalmente comparada à região de Abadiânia-Pirenópolis, as duas regiões podem estar localizadas em diferentes lâminas de cavalgamento e terem sofrido diferentes processos de imbricação interna. Pode-se, no entanto, de acordo com a conclusão apresentada por Teixeira \& Danni (1978) e por Heilbron et al. (1987), afirmar que não há diferenças estruturais e metamórficas que justifiquem a separação dos "Grupos Araxá e Canastra".

Na porção sul de Minas Geria e Norte de São Paulo, Campos Neto et al. (1984) propõem o cavalgamento das unidades granulítica e gnáissica do "Maciço de Guaxupé" sobre os "Grupos Andrelândia e São João Del Rei" durante o Proterozóico Superior, que, por sua vez, tem sido correlacionados ao "Grupo Araxá-Canastra" (Trown et al 1984, Campos 1985). Além disso, Vasconcellos (1988) relata a presença de "anfibolitos" alojados nestas unidades metassedimentares e descreve faixas lineares de cisalhamento com direção aproximada ENE, que deformam a forte foliação que marca aquele cavalgamento. Estas características gerais sugerem que a região pode, tentativamente, ser correlacionada à região de Abadiẩnia-Pirenópolis.

Discussão dos dados de gravimetria Uma feição importante da região abrangida pelos metassedimentos "Araxá e Canastra" são branquianticlinais com eixo maior aproximadamente N-S, que podem representar a influência de uma superfície deformacional N-S, como foi reconhecido para $\mathrm{K}_{2}$ na porção sudoeste da região de Abadiânia. Destas estruturas, destaca-se aquela da região de Caldas Novas, à qual está associado um baixo gravimétrico (Fig. 6) não observado nas demais e que tem sido alvo de alguns levantamentos gravimétricos. Na observação do mapa de anomalias Bourger de Davino (1979), percebe-se uma boa correspondência entre os altos gravimétricos que marcam a borda do grande baixo e a ocorrência de rochas granito-gnáissicas referidas ao "Complexo Basal de Goiás". De outro modo, Barreto \& Costa (1981) limitam a abrangência do seu levantamento gravimétrico ao redor da estrutura dômica de Caldas Novas e, por modelamento geométrico da anomalia de deficiência de massa, indicam a forma de hemi-cilindro deitado com uma espessura mínima de $1 \mathrm{~km}$. Esta espessura contrasta fortemente com o resultado fornecido por Davino (1979): 10 a $12 \mathrm{~km}$.

$\mathrm{O}$ espessamento de unidade geológicas em regiões com importantes cavalgamentos pode ter origem a partir de imbricamentos internos de uma lâmina de cavalgamento na forma de empacotamentos antiformais. A sugestão de uma estrutura deste tipo para a janela estrutural de Caldas Novas (Drake 1980) justificaria a forma geométrica determinada para a sua anomalia gravimétrica.

A correlação das rochas sedimentares que ocorrem no núcleo da janela estrutural de Caldas Novas tem sido usualmente feita com os metassedimentos do Grupo Paranoá e não com os metassedimentos do Grupo Bambuí como pretendeu Drakl (1980). Portanto, o transporte mínimo sofrido pela lâmina de cavalgamento à qual pertencem os metassedimentos Araxá naquela região foi de aproximadamente $100 \mathrm{~km}$.

$\mathrm{O}$ exemplo ilustra a influência da estruturação e do tipo litoló gico envolvido sobre a carta de anomalia gravimétrica Bouguer. A comparação detalhada entre a carta de anomalia gravimétrica Bouguer (Fig. 6) e o mapa geológico apresentado na figura 4 mostra uma significativa correlação entre a faixa de alto gradiente gravimétrico (anomalia do tipo I do Hasui \& Haralyi 1985) e a exposição de grandes áreas compostas por rochas granito-gnáissicas ou granulíticas referidas ao "Complexo Basal" de Goiás e por rochas metassedimentares referidas ao "Grupo Araxá". Para Haralyi et al (1985) e para Hasui \& Haralyi (1985), a duplicação dos níveis crustais profundos no bloco de anomalia positiva e das seqüências metassedimentares no bloco de anomalia negativa responde pelo elevado gradiente gravimétrico observado. Do mesmo modo, é

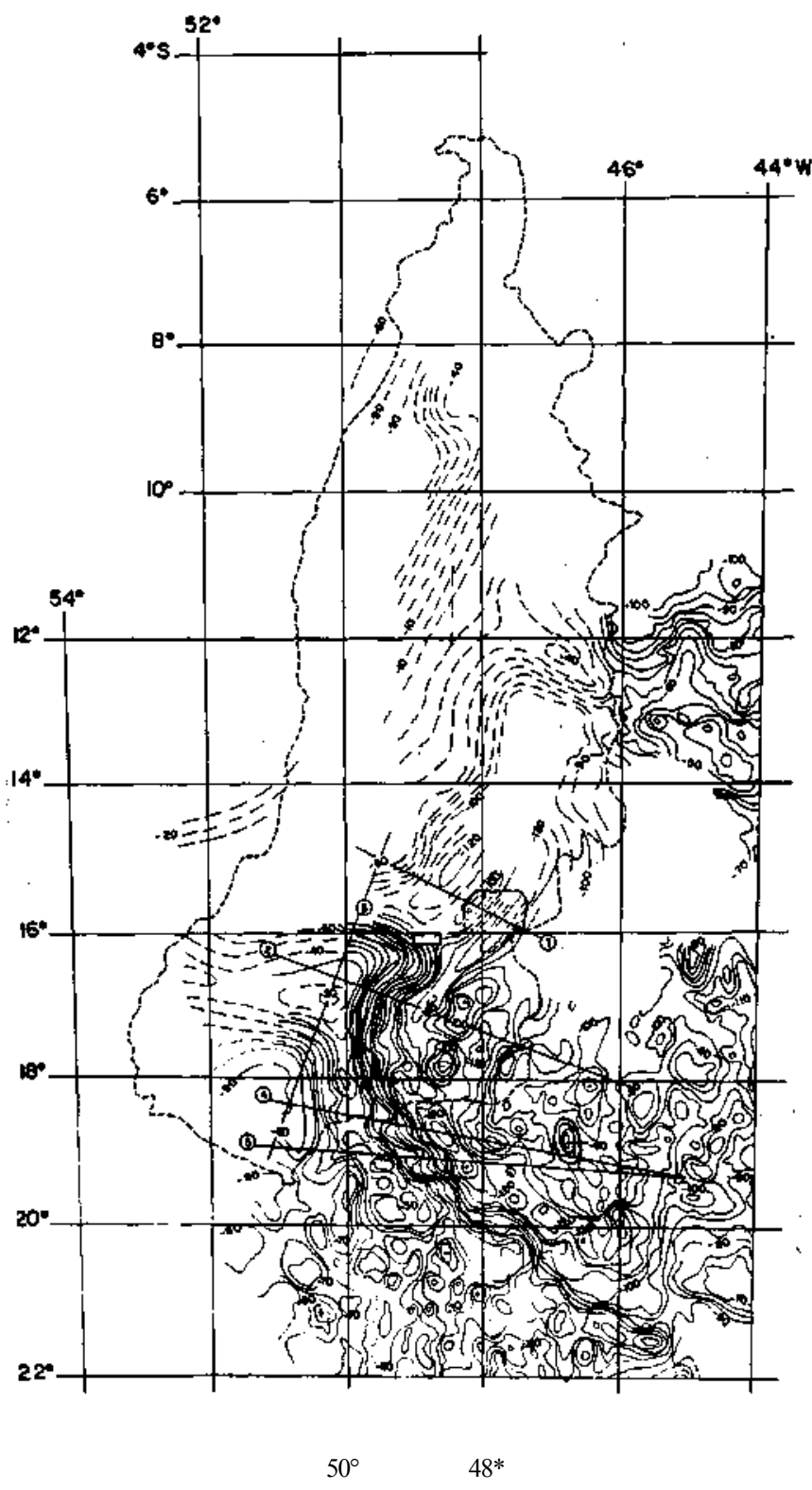

Figura 6 - Mapa de anomalias gravimétricas Bouguer $(d=$ $\left.2,67 \mathrm{~g} / \mathrm{cm}^{3}\right)$ do Centro-Oeste brasileiro segundo Hasui \& Haralyi (1985)

Figure 6 - Bouguer gravimetric anomaly map $\left(\mathrm{d}=2,67 \mathrm{~g} / \mathrm{cm}^{3}\right)$ of CentralWestern Brazil according to Hasui \& Haralyi (1985)

possível correlacionar feições gravimétricas de menor intensidade com feições estruturais colocadas entre o "Grupo AraxáCanastra" e o Grupo Bambuí (anomalias do tipo II de Hasui \& Haralyi 1985). Essas feições gravimétricas também devem refletir um espessamento de determinadas porções de rochas supracrustais e devem representar o resultado de imbricações ou de duplicações tectônicas de unidades compostas por rochas metassedimentares com densidade contrastante.

As anomalias gravimétricas do tipo I adquirem, neste momento, grande importância por representarem feições profundas, às quais, como pode ser percebido na comparação das figuras 4 e 6 , estão relacionadas as unidades "homotaxiais do Grupo Araxá". A importância disso advém na medida em que, a exemplo do que ocorre para os metassedimentos Araxá a sul da Inflexão do Pirineus, estas unidades possam vir a ser caracterizadas como melanges ofiolíticas e, portanto, representar depó sitos de calha de subdução (zonas de sutura).

As anomalias gravimétricas do tipo III, por seu turno, têm sido referidas a extensos lineamentos com componentes horizontais de rejeito que introduziram deslocamentos na geometria regional delineada pelas anomalias do tipo I (Hasui \& Haralyi 
1985). Esta interpretação ganha significado com o reconhecimento das superfícies de deslocamento direcional $\mathrm{K}_{1}$ na região de Abadiânia (Strieder 1989,1990) e tem importância na medida em que é caracterizada a sua ligação cinemática com o deslocamento diferencial de expressivas lâminas de cavalgamento. Contudo, a falta de informações geológico-estruturais suficientes e voltadas para o estudo deste tipo de condicionamento tectônico traz grandes dificuldades na interpretação dos mapas de anomalia Bouguer, como pode ser constatado para este tipo especial de anomalia gravimétrica; a extensão e a articulação dos lineamentos resultantes da interpretação das anomalias do tipo III sofreram algumas modificações desde o primeiro trabalho de Haralyi \& Hasui (1981) até a sua versão mais atual, onde Hasui \& Haralyi (1985) fornecerem extensões menores e orientação predominante em torno de E-W para estas anomalias. Assim, a série de lineamentos E-W e WNW-ESE apresentados na figura 4 está praticamente restrita às unidade tidas até então como integrantes da "Faixa Uruaçuana" e devem marcar superfícies ao longo das quais houve deslocamentos diferenciais de Lâmina de cavalgamento.

$\mathrm{Na}$ região da Inflexão dos Pirineus, a anomalia gravimétrica do tipo III tem certamente um caráter profundo. Contudo, as características estruturais definidas na região não dão suporte à interpretação de Hasui \& Haralyi (1985) que envolve processos de obducção-subducção dupla para esta feição. As características deste lineamento gravimétrico e estrutural são melhor interpretadas como uma "sintaxe" tectônica que envolve o underthrusting de uma placa continental com formato em cunha (Tapponnier \& Moinar 1976, Coward 1983) e o possível aprisionamento de pequenas placas ou arcos-de-ilha entre duas massas continentais principais. Assim, a inflexão dos Pirineus deve possuir uma estrutura do tipo strike-slip subduction (subducção por falhas direcionais).

A forte anomalia gravimétrica do tipo I que marca a ocorrência das unidades geológicas similares aos metassedimentos Araxá prolonga-se para sul, segmentada pelas anomalias do tipo III (Fig. 6), até a região do "Maciço de Guaxupé". Embora os dados gravimétricos para sul daquela região ainda sejam escassos, é possível perceber que a anomalia gravimétrica do tipo I contorna a ocorrência das rochas granulíticas e gnáissicas que compõem o "maciço". Este padrão gravimétrico possui semelhanças com aquele presente na região da inflexão dos Pirineus e, como analisado anteriormente, está marcado por linhas estruturais que também se assemelham àquelas da região de Abadiânia. No entanto, ao contrário da estrutura definida para a inflexão dos Pirineus, o "Maciço de Guaxupé" parece constituir o overthrusting de uma placa continental com formato em cunha durante o mesmo episódio de convergência crustal que deu origem a atual configuração estrutural de toda a região Centro-Oeste; desta forma, o arcabouço tectônico da região de Guaxupé poderia ser descrita como uma "antitaxe" tectônica.

Assim, a estruturação regional em grandes blocos articulados por zonas de subducção (Hasui \& Haralyi 1985, Haralyi et al. 1985) ganha um novo significado tectônico, pois, embora todo o processo de convergência de placas possa ter durado um longo período de tempo, a evolução tectônica regional não envolve sucessivas reativações em vários ciclos orogênicos como propõem estes e outros autores. Por fim, deve-se ressaltar que a caracterização mais exata do posicionamento da zona de raiz para os cavalgamentos que envolvem a melange ofiolítica dos metassedimentos Araxá, a sul da inflexão dos Pirineus, não está clara, pois há importantes registros destas rochas a oeste da área marcada pela anomalia gravimétrica do tipo I.

Discussão dos dados geocronológicos Embora a presença de importantes cavalgamentos e nappes favoreça a vinculação tectônica das unidades referidas acima a um único ciclo orogênico, caracterizado por várias fases de deformação e de metamorfismo, datações geocronológicas de caráter regio- nal têm sido usadas, no Centro-Oeste brasileiro, como suporte à separação de duas faixas de dobramentos evoluídas em diferentes períodos: a Faixa Uruaçu, essencialmente formada pelo "Grupo Araxá" e suas unidades homotaxiais e que evoluiu no Ciclo Uruaçuano, e a Faixa Brasília, formada pela Formação Ibiá, pelo Grupo Paranoá e pelo Grupo Bambuí e que evoluiu no Ciclo Brasiliano (Almeida et al. 1976, Marini et al 1979, Marini et al. 1984).

Uma avaliação superficial dos dados geocronológicos do Centro-Oeste (Hasui \& Almeida 1970, Hasui et al 1980, Tassinari et al 1981, Reis \& Cordani 1984) mostra que, até o momento, as idades utilizadas como parâmetro na discussão da evolução tectônica da região são principalmente isócronas $\mathrm{Rb} / \mathrm{Sr}$ de referência. Muitas idades são de qualidade duvidosa por serem tomadas de diagramas isocrônicos com grande dispersão de pontos; essa dispersão faz com que sejam traçadas várias linhas paralelas ou oblíquas, que possuem desvio padrão muito alto e que indicam estarem sendo correlacionados tipo litológicos cujo caráter cogenético não está claro. Contudo, não parece haver razão para que o primeiro metamorfismo dos metassedimentos Araxá, ou das suas unidades homotaxiais tenha uma idade superior a 850-1000 Ma, como mostram datações K/Ar em anfibolitos (Hasui \& Almeida 1970), ou alguns diagramas isocrônicos de referência apresentados pelos demais autores. A idade de resfriamento total do sistema está ao redor de 500-600 Ma, como sugerem as datações K/Ar em micas dos metassedimentos Araxá (Hasui \& Almeida 1970). Estes dados são compatíveis com o início da sedimentação dos Grupos Paranoá e Bambuí: idade ao redor de 950 e $1100 \mathrm{Ma}$ obtida a partir da análise de estruturas estromatolíticas (ver Campos 1979, para apreciação). As datações radiogênicas de 850-780 Ma, pelo método $\mathrm{Pb}-\mathrm{Pb}$ (Amaral 1968, Cassedanne et al 1972), e de 560-870 Ma, pelo método $\mathrm{Rb} / \mathrm{Sr}$ (Amaral \& Kawashita 1967, Thomaz \& Lima 1981) indicam a idade dos eventos metamórfico-deformacionais finais que estão impressos nos metassedimentos do Grupo Bambuí.

Assim, não parece ser necessário admitir a existência de uma intervalo tectônico entre a unidade de metassedimentos Araxá-Canastra e os Grupos Paranoá e Bambuí. A sedimentação, deformação e metamorfismo num único evento tectônico marcado por importantes processos de cavalgamento responde bem aos diversos problemas de correlação entre aquelas unidades e, também, aos problemas enfrentados no estabelecimento dos limites das duas possíveis faixas de dobramento de natureza completamente independente (ver discussão destes problemas em Marini et al 1984).

COMENTÁRIOS FINAIS A dificuldade e as divergências da regionalização das interpretações tectônicas surgem da falta de mapeamento geológico-estrutural adequado que permita definir com mais clareza a extensão, a organização e as relações dos litotipos comumente mapeados como "Complexo Granito-Gnáissico", ou como "Complexo Granulítico" e que fornecem idades radiométricas não relacionáveis ao evento tectônico que resultou na atual estruturação (1000 - 560 Ma. É importante lembra que os processos deformacionais envolvidos em zonas de convergência de placas podem capturar unidades geológicas formadas em eventos anteriores e reestruturá-los completamente, de acordo com as suas exigências de acomodação interna. É neste sentido que a coluna estratigráfica apresentada na figura 4 não especifica idades geológicas, principalmente para as rochas que compõem os complexos granito-gnáissicos e granulíticos indiferenciados; estas rochas certamente têm como limites a idade das seqüências greenstone belts e a idade da melange ofiolítica contida no "Grupo Araxá" e em algumas de suas unidades homotaxiais (Proterozóico Superior).

Uma proposta de evolução da atual estruturação tectônica de toda a região de dobramentos do Brasil Central em urn único Ciclo Tectônico já foi anteriormente apresentada 
por Costa \& Angeiras (1971), que a denominaram Plataforma Epi-Baykaliana do Brasil Central, a dividiram em Zonas Tectônicas e em Tectonogrupos e a interpretaram dentro dos conceitos geotectônicos do Modelo Geossinclinal. Porém, o ponto mais importante daquele trabalho é que uma mesma unidade geológica ("formação") pode estar envolvida em mais de um tectonogrupo e que a divisão e a descrição dos vários tectonogrupos deixa a impressão de que o levantamento das lâminas de cavalgamento e da sua organização e composição internas podem, ao final, retomar muito da delimitação original proposta por aqueles autores.

Mais recentemente, Cordani \& Brito Neves (1982) propõem uma redefinição da Província Estrutural do Tocantins (Almeida 1977) com a utilização do conceito de faixas móveis. A Província Estrutural do Tocantins seria uma entidade tectônica estruturada inteiramente durante o Ciclo Brasiliano com o desenvolvimento de duas faixas móveis: (a) ParaguaiAraguaia e (b) Brasília. Cordani \& Brito Neves (1982) admitem, pela primeira vez, a possibilidade de ocorrência de amplos deslocamentos horizontais que modificaram as condi- ções paleogeográficas dos terrenos envolvidos; consideram, também, que alguns importantes lineamentos tectônicos podem responder por "translações" de massas continentais, marcar limites de blocos tectônicos e separar fragmentos crustais de diferentes litologias e evolução geológica.

Assim, em termos gerais, é possível manter a redefinição da Província Estrutural do Tocantins, conforme elaborada por Cordani \& Brito Neves (1982). Porém, é necessário haver uma reformulação na concepção de evolução tectônica da província; nesta reformulação, a aplicação do conceito de faixas móveis deve ser substituído por conceitos mais abrangentes de tectônica global, onde vários processos, além de cavalgamentos e de transcorrências, estão intimamente relacionados em regiões de convergência crustal (Schermer et al. 1984).

Agradecimentos Os autores agradecem ao professor Reinhardt A. Fuck pela leitura, comentários e sugestões que permitiram melhorar a versão final deste trabalho. Os autores agradecem também aos revisores da Revista pelos comentários e pelas melhorias sugeridas para a apresentação do artigo.

\section{REFERÊNCIAS BIBLIOGRÁFICAS}

ABREU, F.A.M. 1978. O Supergrupo Baixo Araguaia. In: CONOR. BRAS. GEOL, 30. Recife, 1978. Anais... Recife, SBG/NE. v. 2, p. 239-545.

ABREU, F.A.M. \& HASUI, Y. 1978. Evolução estrutural do Supergrupo Baixo Araguaia. In: CONOR. BRAS. GEOL., 30. Recife, 1978. Anais... Recife, SBG. v. 1, p. 257-269.

ALMEIDA, F.F.M. 1969. Evolução tectônica do Centro-Oeste brasileiro no Proterozóico Superior. An. Acad. bras. Ciên., 40(supl.):285-295.

ALMEIDA, F.F.M. 1971. Geochronological division of the Precambrian in South America. Rev. Bras. Geoc., 1(1):13-21.

ALMEIDA, F.F.M.; HASUI, Y.; BRITO-NEVES, B.B. 1976. The Upper Precambrian of south America. Bol IG/USP 7:45-80.

AMARAL, G. 1969. Resultados preliminares do estudo sobre a mineralização e composição isotópica em galenas de depósitos encaixados no Grupo Baubuí. In: CONGR. BRAS. GEOL., 20. Belo Horizonte, 1968. Resumos.. Belo Horizonte, SBG. p. 51-53.

AMARAL, G. \& KAWASHITA, K. 1967. Determinação da idade do Grupo Bambuí pelo método Rb/Sr. In: CONGR. BRAS. GEOL., 21. Curitiba, 1987. Anais... Curitiba, SBG. p. 214-217

ANGEIRAS, A.G. 1969. A faixa de serpentinitos da região central de Goiás. An. Acad. bras. Ciên., 40(supl.):129-136.

ARAÚJO, J.D., P 1981. Contribuição à estratigrafia e tectônica da região da mega-inflexão dos Pirineus - Goiás Centro Meridional. In: SIMP GEOL. CENTRO-OESTE, 1. Goiânia, 1981. Resumos... Goiânia, SBG. p. $24-27$.

ARAUJO, J.D., P \& LEONARDOS, O.H. 1986. A esmeralda do município de Pirenópolis, Goiás: um exemplo de greisenização de talco xistos. In CONGR. BRAS. GEOL., 34. Goiânia, 1986. Anais... Goiânia, SBG. v. 4, p. $1835-1845$.

ARAÚJO, V.A.; MATIAS, P.V.B.; GODOI, H.O.; ARAÚJO, E.S.; MORETON, L.C.; SILVA, M.A. 1980. Projeto Pontalina. Goiânia, CPRM. v. 1, 227 p. (Relatório Fase 1).

BALLANCE, P.F. \& SPRLI, K.B. 1979. Northland allochthon. In: MacCall, G.J.H. ed. Ophiolitic and Related Melanges. 1983. Stroudsburg/USA, Hutchinson Ross. Publ. p. 387-399. (Benchmark Papers in Geology 66).

BARBOSA, O. (coord.). 1970. Projeto Goiânia. Con v. PROSPEC/DNPM MME. 75 p.

BARBOSA, P.A.R. 1987. Geologia e Recursos Minerais das Seqüências Supracrustais a Leste de Mossâmedes (GO). Brasília. 229 p. (Dissertação de Mestrado, IE/UnB).

BARRETO, J.A., P \& COSTA, J.F.G. 1981. Gravimetria na Região de Caldas Novas. Eletroprojetos/CPRM. 9 p. (Relatório Final).

BATISTA, M.B. 1969. Projeto Goiânia, Folha Morrínho. Conv. PROSPEC/ DNPM/MME. 31 p. (Relatório Preliminar).

BERBERT, C.O.1970. Geologia dos complexos básicos-ultrabásicos de Goiás. In: CONGR. BRAS. GEOL., 24. Brasília, 1970, Anais... Brasília, SBG. p. $41-50$.

BERBERT, C.O.; CORRÊA, J.A.; MELLO, J.C.R. 1970. Geologia da área de Interlândia-Abadiânia. Goiás. Rio de Janeiro, DNPM. 59 p. (Boletim 135)

BRAUN, O.P.G. 1969. Projeto Goiânia - Folha Ipameri. Conv. PROSPEC/ DNPM. 42 p. (Relatório Preliminar).

CAMPOS, M.C., Neto 1979. Contribution a Létude des Brasilides Lithostratigrqfie et structures des Groupes Canastra, Paranoá et Bambui dans l'Ouest-Nord-Ouest de 1'Etat de Minas Gerais, Brésil. França. 195 p. (These de $3^{\text {ème }}$ Cycle, Université Pierre et Marie Curie).
CAMPOS, M.C., Neto. 1985. Evolução do pré-cambriano paulista e regiões adjacentes. In: SIMP. REG. GEOL., 5. São Paulo, 1985. Atas... São Paulo, SBG. v. 2, p. 581-571.

CAMPOS, M.C., Neto; BASEI, M.A.S.; ALVES, F.R.; VASCONCELLOS, A.C.B.C. 1984. A nappe de Cavalgamento Socorro, SP-MG. In: CONGR BRAS. GEOL. 33. Rio de Janeiro, 1984. Anais... Rio de Janeiro, SBG. v. 4, p. 1908-1922

CASSEDANNE, J.; DUTHOU, J.L.; LASSERRE, M. 1972. Análise isotópicas pelo método do chumbo de uma terceira série de galenas brasileiras. Min. Metal., 36(335):12-19.

COLEM AN, R.G. 1977. Ophiolites: Ancient Oceanic Uthosphere? BerlinGermany, Springer-Verlag. 229 p.

CORDANI, U.G. \& BRITO-NEVES, B.B. 1982. The geologic evolution of South America during the Archean and Early Proterozoic. Rev. Bras. Geoc., 12(1-3):78-88.

CORDEIRO, A.A.C \& McCANDLESS, G. 1976. Macico ultramáficos de Quatipuru. In: CONGR. BRAS. GEOL., 29. Ouro Preto, 1976. Anais.. Ouro Preto, SBG. v. 3, p. 9-15.

CORRÊA, J.A. \& BITTENCOURT, C.M. 1969. Mapeamento geológico de área de Goiânia-Bonfinópolis, Goiás. In: CONGR. BRAS GEOL., 22. Belo Horizonte, 1969. Anais... Belo Horizonte, SBG. v. 3, p. $9-15$.

CORREAA, J.A. \& SOBRINHO, M.L. 1969. Mineralizações de cromo, níquel e talco lamelar em Maiipotaba, Goiás. In: CONGR. BRAS. GEOL., 23. Salvador, 1969. Resumos... Salvador, SBG. p. 24.

COSTA, L.A.M. \& ANGEIRAS, A.G. 1971. Geosynclinal evolution of the Epi-Baykalian plataform of Central Braszil. Geol. Raunschau, 60(3): 1024-1050.

COWARD, M.P. 1983. Thrust tectonics, thin skinned or thick skinned and the continuation of thrusts to deep in the crust. J. Struct Geol., 5(2): 113-123.

DANNI, J.C.H. \& TEIXEIRA, N.A. 1981. Caracten'siticas e sistematização das associações de rochas máficas e ultramáficas Pré-Cambrianas do Estado de Goiás. In: SIMP. GOL. CENTRO-OESTE, 1. Goiânia, 1981. Atas... Goiânia, SBG-CO/BSB. p. 376-401.

DARDENNE, M. A. 1978. Zonação tectônica na borda ocidental do Cráton do São Francisco. In: CONGR. BRÁS. GEOL., 30. Recife, 1978. Anais... Recife, SBG-NNE. v. 1, p. 298-308.

DAVINO, A. 1979. O baixo gravimétrico da região de Caldas Novas, Goiás. In: SIMP. REG. GEOL., 2. Rio Claro, 1979. Atas... Rio Claro, SBG. p. $87-100$.

DRAKE, A.A., Jr. 1980. The Serra de Caldas Window, Goiás. USGS. Prof. Paper, 1119(1-B):A1-A11.

FUCK, R.A. \& M ARINI, O.J. 1979.0 Grupo Araxá e unidade homotaxiais. In: SIMP. CRATON DO SÃO FRANCISCO E SUAS FAIXAS MARIGINAIS, I.Salvador, 1979. Anais... Salvador,SBG.p. 118-130.

GANSSER, A. 1974. The ophiolitic melanges, a world-wide problem on Tethyan examples. In: MacCall, G.J.H. ed. Ophiolitic and Related Melanges. 1983. Stroudsburg/USA, Hutchinson Ross. Publ. p. 387-399. (Benchmark Papers in Geology 66).

GORAYEB, P.S.S. 1989. Corpos serpentínicos da Faixa Araguaia na região de Araguacema-Pequizeiro-Conceição do Araguaia (Goiás-Pará). Rev. Bras. Geoc., 19(1):51-62.

HARALYI, N.L.E. \& HASUI, Y. 1981. Anomalias gravimétricas e estruturas maiores do Sul de Goiás. In: SIMP. GEOL. CENTRO-OESTE. Goiânia, 1981. Atas... Goiânia, SBG/NCO. p. 73-92. 
HARALYI. N.L.E.; HASUI, Y; MIOTO, J.A.; HAMZA, V.M.; RODRIGUES, C.R.V. 1985. Ensaio com base na informação geofísica e geológica. Contribuição à Geologia e à Petrologia. Belo Horizonte, SBG/NMG. p. 71-83.

HASUI, Y.; ABREU, F.A.M.; SILVA, J.M.R. 1980a. Estratigrafia da faixa de dobramentos Paraguai-Araguaia no Centro-Norte do Brasil. Bol. IG/USP. 8:107-118.

HASUI, Y. \& ALMEIDA, F.F.M. 1970. Geocronologia do Centro-Oeste brasileiro. Bol. Soc. Bras. Geol., 19(1):5-26.

HASUI, Y. \& HARALYI, N.L.E. 1985. A mega-estruturação de Goiás. In: SIMP. GEOL. CENTRO-OESTE, 2. Goiânia, 1985. Atas... Goiânia, SBG. p. 120-144.

HASUI, Y; TASSINARI, C.C.G.; SIGA, O., Jr.; TEIXEIRA, W.; ALMEIDA, F.F.M.; KAWASHITA, K. 1980b. Datações Rb/Sr e K/Ar do Centro-Norte do Brasil e seu significado geológico-tectônico. In: CONOR. BRAS. GEOL., 31. Camboriú, 1980. Anais... Camboriú, SBG. v. 5, p. 2659-2676.

HEILBROW, M.; VALERIANO, C.M.; ZIMBRES, E.; CHRISPIM, S.J.; SIMÕES, L.S.M.; SOUZA, M.A.T. 1987. O contato basal do Grupo Canastra entre Itaú de Minas e Carmo do Rio Claro, MG. In: SIMP.

GEOL. MINAS GERAIS, 4. Belo Horizonte, 1987. Atas... Belo Horizon-

te, SBG. p. 179-198.

HENDERSON, J.R. 1981. Structural analysis of sheath folds with horizontal Xaxes, northeast Canada. J Struct. Geol., 3(3):203-210.

HSU, K.J. 1968. Franciscan melanges and their bearing on the FranciscanKnoxvilie paradox. Geol. Soc. Am. Bull., 79(5): 1063-1074.

HSU, K.J. 1974. Melanges and their distinction from ollstostromes. In: MacCall, G.J.H. ed. Ophiolific and Related Melanges. 1983. Stroudsburg/USA, Hutchinson Ross. Publ. p. 50-62. (Benchmark Papers in Geology 66).

LACASSIN, R. \& MATTAUER, M. 1985. Kilometer-scale seath fold at Mattmark and implictions for transport direction in the Alps. Nature, 315(6022):739-742.

LAGARDE, J.L. \& MICHARD, A. 1986. Stretching normal to the regional thrust displacement in a thrust-wrench shear zone, Rehamna Massif, Morocco. J. Struct. Geol., 8(3/4):483-492.

LEONOV, M.G. 1978. Olistostrome and their origin. Geotectonics, 12:333-342.

MALPAS, J. \& STEVENS, R.K. 1977. The origin nd emplacement of the ophiolite suite with exmples from Western Newfoundlnd. Geotectonics, 11(6):453-466

MALTMAN, A.J. 1978. Serpentine textures in Anglesey, North Wales, United Kingdom. Geol. Soc. Am. Bull., 89(7):972-980.

MARINI, O.J.; DARDENNE, M.A.; FUCK, R.A.; DANNI, J.C.M. 1979a Mapa Geológico da Faixa Brasilia, Escala 1:2.000.000. Brasília, UnB. (Publicação Interna)

MARINI, O.J.; FUCK, R.A.; DANNI, J.C.M.; DARDENNE, M.A. 1979b. A evolução geotectônica da Faixa Brasília e do seu embasamento. In: SIMP. SOBRE O CRÁTON DO SÃO FRANCISCO E SUAS FAIXA MARGINAIS, 1. Salvador, 1979. Anais... Salvador, SBG. p. $100-115$.

MARINI, O.J.; FUCK, R.A.; DANNI, J.C.M.; DARDENNE, M.A.; LOGUERCIO, S.O.C.; RAMALHO, R. 1984. As faixas de dobramentos Brasília, Uruaçu e Praguai-Araguaia e o Maciço Mediano de Goiás. In: SCHOBBENHAUS, C.; CAMPOS, D.A.; DERZE, G.R.; ASMUS, H.E. coord. Geologia do Brasil. Rio de Janeiro, DNPM. 501 p.

MARTINS, E.S. \& ROESNER, E.H. 1986. Projeto Santa Cruz: Geologia da área Maratà. Brasília. 241 p. (Relatório de Graduação, IG/UnB)

McCALL, G.J.H. ed. 1983a. Ophiolitic and Related Melanges. Stroudsburg/ USA, Hutchinson Ross Publishing. 446 p. (Benchmark Papers in Geology 66).

McCALL, G.J.H. ed. 1983b. Melanges of the Makran, Southeastern Iran. In: MacCall, G.J.H. ed. Ophiolitic and Related Melanges. 1983. Stroudsburg/USA, Hutchinson Ross. Publ. p. 292-299. (Benchmark Papers in Geology 66).

MELLO, J.C.R. \& BERBERT, C.O. 1969. Investigação Geológico-Econômica da Área de Morro Feio-Hidrolâudia, Goiás. Brasília, Conv. DNPM/ CPRM/MME. 73 p. (Boletim 132).

MELLO, J.C.R.; BERBERT, C.O.; CORRÊA, J.A. 1968. Ocorrências minerais de importância nas ultrabásicas de Interlândia-Abadiânia, Goiás. In: CONGR. BRAS. GEOL., 22. Belo Horizonte, 1968. Anais... Belo Horizonte, SBG/NMG. v. 3, p. 235-239.

MILLIOTI, C. A. 1978. Distribuição e Controle da Mineralização de Platina no Morro Feio $(G O)$. Brasília. 140 p. (Dissertação de Mestrado, $\mathrm{IG} / \mathrm{UnB})$.
NILSON, A.A. 1981. The Nature of the Americano do Brasil MaficUltramafic Complex and Associated Sulfide Mineralization, Goiás, Brazil. USA. 460 p. (PhD Thesis, University Western Ontario).

NILSON, A. A. 1984.0 atual estágio de conhecimento dos complexos máficoultramáficos pré-cambrianos do Brasil - uma avaliação preliminar. In: CONGR. BRAS. GEOL., 33. Rio de Janeiro, 1984. Anais... Rio de Janeiro, SBG. v. 4, p. 4166-4203.

NILSON, A. A.; CORREAA, J.A.; MELLO, J.C.R.; FIGUEIREDO, A.N.; REIS, A.G.L.; BAETA, J.D., Jr.; JUSTO, L.J.E.C.; SOBRINHO, M.L. 1969. Geologia da região de Cromínia-Pontalina, Goiás. In: CONGR. BRAS. GEOL., 23. Salvador, 1969. Resumos... Salvador, SBG. p. 70-71.

NILSON, A. A. \& REIS, A.G.L. 1969. A jazida de amianto-crisotila do Morro Dois Irmãos, Município de Pontalina, Goiás. In; CONGR. BRAS. GEOL., 23. Salvador, 1969. Resumos... Salvador, SBG. p. 32

PENA, G.S. coord. 1975. Projeto Goiânia II. Brasília, Conv. DNPM/CPRM/ MME. v. 1, 249 p. (Relatório Final).

RATTEY, P.R. \& SANDERSON, D.J. 1982. Patterns of folding within nappes and thrust sheets: examples from the Variscan of Southwest England. Tectonophysics, 88(2):247-267.

REIS, J.H., Neto \& CORDANI, U.G. 1984. Influência do evento geodinâmico brasiliano nos resultados radi me tricôs do Centro-Oeste brasileiro. In:

CONGR. BRAS. GEOL., 33. Rio de Janeiro, 1984. Anais... Belo Horizonte, SBG/NRJ. v. 2, p. 2276-2288

RIDLEY, J. 1982. Arcuate lineation trends in a deep level, ductile thrust belt, Syros, Greece. Tectonophysics, 88(1/2):347-360.

ROBERTSON, A.H.F. 1977. The Moni Melange, Cyprus: and olistostrome formed at a destructive pile margin. J. Geol. Soc. London., 133:447-450, 454-466.

ROSITO, J. \& ARAÚJO, L.V.A. 1969. Nova jazida de cromita no município de Pirenópolis, Goiás. In: CONGR. BRAS. GEOL., 23. Salvador, 1969. Resumos... Salvador, SBG/NBA. p. 37-38.

SANDERSON, D.J. 1982. Models of strain variation in nappes and thrust sheets: a review. Tectonophysics, 88(1/2):201-233.

SCHERMER, E.R.; HOWELL, D.G. \& JONES, D.L. 1984. The origin of allochtonous terranes: perspectives on the growth and shaping of continents. Ann. Rev. Earth Planet. Sci., 12:107-131.

SCHMIDT, W. \& FLEISCHER, R. 1978. Estilo estrutural do Pré-Cambriano no sudoeste de Minas Gerais. In: CONGR. BRAS. GEOL., 30. Recife, 1978. Anais... Recife, SBG/NNE. v. 1, p. 438-434.

SIMÕES, L.S.A. 1984. Geologia do Gr. Araxá na Região de Mossâmedes GO, e as Ocorrências Minerais Associadas. Brasília. 219 p. (Dissertacão de Mestrado, IG/UnB).

STRIEDER, A.J. 1989. Geologia, Petrologia e Tectônica dos Corpos de Serpentinitos de Abadiânia (GO). Brasília. 208 p. (Dissertação de Mestrado, IG/UnB).

STRIEDER, A.J. 1990. Análise estrutural na região de Abadiânia (GO). Rev. Bras. Geoc., 20(1-4):239-257.

TAPPONN1ER, P. \& MOLNAR, P. 1976. Slip-line theory and large-scale continental tectonics. Nature, 264:319-324.

TASSINARI, C.C.G.; SIGA, O, Jr.; TEIXEIRA, W. 1981. Panorama geocronológico do Centro-Oeste brasileiro, soluções, problemáticas e sugestões. In: SIMP. GEOL. CENTRO-OESTE, 1. Goiânia, 1981. Atas. Goiânia, SBG/NCO/BSB

TEIXEIRA, N.A. \& DANNI, J.C.M. 1978. Contribuição a estratigrafia do Grupo Araxá na região de Passos - MG. In: CONGR. BRAS. GEOL., 30. Recife, 1978. Anais... Recife, SBG/NNE. v. 3, p. 700-711.

THAYER, T.P. 1970. Notes on the Geology and Resources of some Peridotifes and Related Rocks in Brazil. Washington, U.S. Geol. Survey. 22 p. (Relatório Inédito 800).

THOMAZ, A., P \& LIMA, V.Q. 1981. Datações radiométricas de rochas sedimentares pelíticas pelo método $\mathrm{Rb} / \mathrm{Sr}$. Bol Téc. PETROBRÁS, 24(2): 109-119.

TROUW, R.A.J.; RIBEIRO, A.; PACIULLO, F.V.P.; HEILBRON, M. 1984. Os Grupos São João dei Rei, Caracas e Andrelândia como a continuação dos Grupos Araxá e Canastra. In: CONGR. BRÁS. GEOL., 33. Rio de Janeiro, 1984. Anais... Rio de Janeiro, SBG/NRJ. v. 7, p. 3227-3240.

VASCONCELLOS, A.C.B.C. 1988. O Grupo Andrelândia na Região Norte de Ouro Fino, MG. São Paulo. 199 p. (Dissertação de Mestrado, IG/USP).

MANUSCRITO A626

Recebido em 27 de outubro de 1989 Revisão do autor em 18 de setembro de 1991 Revisão aceita em 18 de setembro de 1991 